\title{
Islamic Psychotherapy In The Pandemic Of Covid-19
}

\section{Sabrida Muhammad Ilyas *)1}

${ }^{1}$ Program Studi Bimbingan dan Konseling Islam, Institut Agama Islam Negeri (IAIN)

Langsa, Aceh, Indonesia.

*1C Corresponding author, ఏe-mail: sabridailyas11@iainlangsa.ac.id

\begin{tabular}{ccc}
\hline Received: & Accepted: & Published: \\
8 May 2020 & 05 June 2020 & 25 June 2020 \\
\hline
\end{tabular}

\begin{abstract}
When God sent disaster in the form of the disease in humans in the world, God also gave instructions on how to deal with and treat it in His book. This paper explains the spiritual values and religiosity through Islamic psychotherapy whose aim is to provide a religious / Islamic nuanced solution to the problem of anxiety disorders and contracting Covid-19 that engulfs the world. The method that I use in this paper is a descriptive analysis method, in which the author presents data from several relevant opinions and tested through various sources then analyzes it, to produce a more effective alternative that is packaged in an appropriate, actual, factual, and contextual method. One approach to dealing with the problem of anxiety disorders and exposure to Covid-19 during a pandemic is through therapy. Sufism patience therapy seeks to optimize and unleash human spiritual energy through three phases. The takhalli phase is the phase in which humans cleanse impurities both physically and the heart, the tahalli phase is where humans learn to decorate themselves or behave with commendable qualities and the tajalli phase is how humans feel a good relationship with God is established. Patience therapy with verses of the Koran specifically to cure all diseases, namely: Quran in Surah Al-Isra 'verses 82, Surah AlAnbiya verses 83-84, and Surah Al-Fatihah verses 1-7.
\end{abstract}

Keywords: Psychotherapy Islam, Pandemic, Covid-19

\begin{abstract}
Abstrak
Ketika Allah Swt menurunkan musibah dalam bentuk penyakit pada manusia di dunia, Dia juga memberikan petunjuk cara menghadapi dan mengobatinya yang dijelaskan dalam kitab-Nya. Tulisan ini menjelaskan tentang nilai-nilai spiritual dan religiusitas melalui psikoterapi Islam yang tujuannya untuk memberikan solusi bernuansa keagamaan /Islam terhadap permasalahan gangguan kecemasan akibat pandemi Covid-19 yang melanda dunia. Metode yang penulis pergunakan dalam tulisan ini adalah metode analisis deskriptif, dimana penulis memaparkan data dari beberapa pendapat yang relevan dan teruji melalui berbagai sumber kemudian menganalisisnya, sehingga menghasilkan sebuah alternatif yang lebih efektif yang dikemas dalam metode yang tepat, aktual, faktual, dan kontekstual. Salah satu pendekatan untuk menghadapi masalah gangguan kecemasan pada masa pandemi Covid-19 ini yaitu melalui terapi kesabaran. Terapi kesabaran tasawuf berusaha mengoptimalkan dan melejitkan energi spiritual manusia dengan melalui tiga fase. Pertama fase takhalli adalah fase dimana manusia membersihkan kotoran baik fisik maupun hati, kedua fase tahalli yaitu dimana manusia belajar untuk menghias diri atau berprilaku dengan sifat-sifat terpuji dan ketiga yaitu fase tajalli adalah bagaimana manusia merasakan terjalinnya hubungan yang baik dengan Allah. Terapi kesabaran dengan ayat-ayat Al-Qur'an yang khusus untuk menyembuhkan segala penyakit yaitu terdapat dalam Al-Qur'an Surah Al-Isra' ayat 82, Surah Al-Anbiya ayat 83-84 dan Surah Al-Fatihah ayat 17.
\end{abstract}

Kata Kunci: Psikoterapi Islam, Pandemi, Covid-19

How to Cite: Ilyas, S. M. (2020). Islamic Psychotherapy In The Pandemic Of Covid-19. ENLIGHTEN: Jurnal Bimbingan Konseling Islam, 3(1), 35-47. https://doi.org/10.32505/enlighten.v3i1.1581

This is an open access article distributed under the Creative Commons Attribution License, which permits unrestricted use, distribution, and reproduction in any medium, provided the original work is properly cited. (C2020 by author. 


\section{INTRODUCTION}

The world in the 3rd millennium or 21st century is being hit by a major disaster facing the coronavirus pandemic. According to the virus expert, Sutejo in Halide (2020) said that the coronavirus or Covid-19 is a disease that has the characteristics of mild symptoms such as colds, sore throats, coughs, and fevers. Other more serious symptoms can cause pneumonia or shortness of breath and death.

Regarding the Covid-19 pandemic subscription, especially in Indonesia, President Joko Widodo in Beritasatu.com has issued Presidential Decree Number 11 of 2020 concerning Determination of Covid-19 Public Health Emergency. It was stressed that Covid-19 is a disease that causes public health emergencies. Therefore, Covid-19 in Indonesia must be addressed by applicable regulations.

With the help of social media, the spread of the epidemic Covid-19 with different versions and sources made the virus worldwide. However, unfortunately, the media still highlight the exploitative side in the form of commodification of their offerings about the virus so that the information becomes confusing. This is felt to have a profound psychological effect on changes in people's behavior, namely by the emergence of moral panic (moral panic), the community becomes more over-protective of the surrounding environment by becoming more easily suspicious of people who cough, sneeze or look pale. Then the emergence of panic buying behavior by going to the market to buy all the stock of food, medicines, and even masks. This phenomenon arises due to its association with excessive anxiety about the antipathy of basic food shortages, contracting, and dying from the Covid-19 virus.

Excessive anxiety can be categorized as a psychological disorder. This disorder prevents a person from living a normal life or being unproductive. Psychologists and others with their knowledge have provided solutions to overcome anxiety during the Covid-19 pandemic, such as drugs, meditation, exercise, positive thinking, or online conversations with friends or loved ones to eliminate anxiety. However, this has not been able to resolve this anxiety disorder problem completely.

The presence of Islamic psychotherapy which originates in the Koran and hadiths is a wealth enhancer in finding solutions to deal with anxiety disorders Covid-19. In Islamic psychotherapy, it is believed that by increasing spiritual and religious humanity will be able to manage its mental functions dynamically. When this Islamic therapy is done properly and correctly, it can direct the individual to the 
reaction to protect themselves from anxiety disorders. For this reason, the author tries to present Islamic psychotherapy to become one of the alternative solutions in overcoming anxiety and healing from the Covid-19 virus which is an enemy of the world today.

\section{METHOD}

The method that I use in this article is a descriptive analysis method. The descriptive analysis method is a method that serves to describe the object under study through data or samples that have been collected (Sugiono: 2009). Here the authors describe data from six positive patients exposed to Covid-19 who successfully recovered and some opinions of relevant therapists and scholars from various analyzes, to produce a more effective alternative.

\section{DISCUSSION}

\section{Psychology of Covid-19 Anxiety}

Communities infected and experiencing deaths due to the Covid-19 pandemic are expected to continue to grow and will last a long time. Then the government policy in each country and the regions the implementation of lockdown policies and physical restrictions or social distancing makes many people have to do activities as usual. Prompts not to leave the house or stay at home make the community have started to feel tired and economic difficulties. Even more so at the level of community groups who have a history of previous illnesses having an impact, making them more anxious, angry, stressed, and anxious and panic. In the study of Disease Control and Prevention (CDC) in China found that those who are at the forefront of rescue, especially survivors and health workers who work harder due to the number of patients exploding at the same time risk of causing mental disorders. They are very likely to develop depression, anxiety, and post-traumatic stress disorder. (Dong \& Bouey, 2020)

Anxiety according to the Medical Dictionary, describes an unpleasant emotional state, in the form of psychophysiological responses that arise as an anticipation of an unreal or imagined danger caused by an intrapsychic conflict that is not directly realized (Dorland, 2010).

In psychology, Sigmund Freud calls it anxiety, having an understanding of anxiety, anxiety, and worry (Kartono \& Gulo 1987). Furthermore, Freud said anxiety is a function of the ego to warn individuals of the possibility of a danger coming so those appropriate adaptive reactions can be prepared.

Syamsu Yusuf as quoted by Annisa and Ifdil (2016) suggests anxiety is neurotic helplessness, discomfort, immature, and lack of ability to deal with the demands of reality (environment), 37

Enlighten, Volume 3 No 1 June 2020 
difficulties, and pressures of daily life. Furthermore, Sutejo (2018) said that anxiety is a feeling of fear of something happening that is caused by anticipation of danger and is a signal that helps individuals to prepare to take action to face a threat.

Freud explained in Suryabrata (2005), there are three types of individual anxiety, namely objective anxiety (Realistics), a type of anxiety that is oriented to aspects of external dangers such as seeing or hearing something that can be bad. Second, neurosis anxiety, is a form of anxiety that if the senses cannot be controlled and cause someone to do something that can be subject to legal sanctions. The third is moral anxiety is a type of anxiety that arises from feelings of intimate feelings of sin when someone does something wrong.

Reported by Britannica, When anxious, the amygdala, the center of anxiety in the brain, responds by activating the autonomic nervous system excessively. The body is made as if it is facing a threat so it is always alert. As a result, psychosomatic symptoms appear namely heart rate and blood pressure increase, creating pain in the chest. World Health Organization (2020) in the discussion of Coronavirus Disease Advice for the Public, explained when constantly reading bad news, such as the death of medical personnel or the increasing number of patients who were positively infected by the Coronavirus, they might feel anxious, afraid, and stressed. This feeling will make the body think that it is in danger, then release the hormone adrenaline and cortisol. Naturally, both of these hormones are produced when the body feels threatened. The aim is to increase the body's response to be ready to face danger.

Yustinus Semium (2010) said symptoms of anxiety will impact four dimensions including symptoms on moods such as depression and irritability and sadness. Cognitive symptoms, such as difficulty concentrating or focusing the mind, feeling disturbed by fear of something that happens in the future, belief that something terrible will happen soon, without any clear explanation, the mind feels mixed or confused, thinking will die soon. Motor symptoms such as motor activities become meaningless, shock at sudden sounds, avoidance behavior, inherent and dependent behavior, and shaken behavior. Symptoms of somatic such as sweating, dry mouth, difficulty breathing, swollen esophagus, frequent urination, rapid pulse increased blood pressure, head throbbing, muscles tense, paresthesias (abnormal skin feeling), such as itching, prickling or burning.

All of the anxiety symptoms related to psychosomatic above can be stated that there are similarities with the symptoms of individuals who have contracted Covid-19. In the study of 
Psychological Predictors of Anxiety in Response to the H1N1 (Swine Flu) Pandemic states there is a relationship between a health crisis with psychosomatic. Based on the results of these studies, it was revealed that a widely publicized health crisis could cause mass psychogenic conditions. (Wheaton, et. al., 2012).

So, many individuals can experience psychosomatic as a result of excessive anxiety when facing Covid-19 Pandemic. Healthy individuals can misinterpret body sensations that are not serious to be similar to the symptoms of Covid-19, such as sore throat, runny nose, feeling unwell or feeling limp, dry cough, fever, and shortness of breath.

\section{Anxiety Quranic Perspective}

From the perspective of the Qur'an, all kinds of emotions (joy, sadness, anxiety, anger, fear) and expressions are created by God through His provisions to form more perfect human beings (Aliah B. Purwakania Hasan, 2008). In His Word:

"And that it is He who makes people laugh and cry and that He is the one who turns off and brings to life (QS Al-Najm [52]: 43-44).

According to Abi al-Qasim alHusain bin Muhammad (2009), the word anxiety in the Qur'an is called khawf yahzan, daiq, halu'a. In Arabic, khawf language is fear, anxiety, doubt, and can also be interpreted as faza that means worry. Khawf means an uneasy heart condition related to future cases or something unfortunate that arises from a hunch. In His Word:

"Or like (people who are overwritten) heavy rain from the sky accompanied by pitch black, thunder and lightning; they clog their ears with their fingers, because (hear the sound) of lightning, for fear of dying. And Allah encompasses those who disbelieve." (AlBaqarah \{2\}: 19).

Yahzan means sad, difficult, and miserable. Sadness is an uneasy heart condition related to the past of the rigors of life and the hardness of the heart which makes it anxiety, misery, and sorrow. In his word

"All of you descend from heaven! Then if My instructions come to you,s whoever follows My instructions, surely there will be no concern for them, and they will not be sad." (AlBaqarah [2]: 38)

Daiq has a narrow meaning of soul or doubt in the heart. The narrowness of the soul is like the feeling doubt that is in the heart of a human being.

"Be patient (O Muhammad) and your patience is not but with the help of Allah and does not grieve towards them (disbelief) and do not be narrowed against what they deceived." (anNahl [16]: 127)

Halu'a means doubt, anxiety, impatience, and eagerness to be kind of greedy. it is found in surah al-Ma'arij [70]: 19 which means, "Verily, humans are created to be stingy and stingy.

Enlighten, Volume 3 No 1 June 2020 


\section{Understanding the Covid-19 Presence}

In essence, everything that is experienced by humans in life in this world, sometimes some things are seen as pleasant or otherwise unpleasant. Everything is a test from Allah. Sometimes some tests are alive to grow like babies born and there are tests to death such as circumstances of death and illness. God's Word:

"... We will test you with evil and goodness as a trial. And you will be returned only to us". " (Al-Anbiya [21]: 35).

All of these tests are essentially mentioned in the Qur'an as a way for us to increase pious deeds

"And it is he who created the death of God and also the life of all of this to test the survivors how they increase their good deeds truly Allah is mighty and most forgiving". (al Mulk: 2)

In the Koran, the tests which often come to unpleasant things are always juxtaposed with patience.

"And we will surely test you with a little fear, hunger, lack of wealth, soul, fruit. And convey the good news to those who are patient." (Al-Baqarah [2]: 155)

Associated with Covid-19 is certainly classified as an unpleasant test in the humanitarian context. How to be patient in the Covid-19 pandemic condition does not mean resignation, silence but with the attitude of accepting all the decisions that God has given accompanied by endeavor and surrender all the results to God to accept that the ridge is patient.
As the experience of some positive patients, Covid-19 who managed to recover by applying the meaning of patience and endeavor has led them to heal with God's permission. Based on the article Tribun Padang.com Saturday edition, April 11, 2020. Aswiliarti (44) positive corona patients in West Sumatra (West Sumatra) who have been declared cured. I made it through the times of crisis by avoiding anxiety and fear and not underestimating the threat of illness by attending treatment procedures in the hospital and still growing hope in God by praying and being patient. Furthermore, Kompas.com, a positive YT patient infected with coronavirus from Mataram City was declared cured by Dr. Herman Mahaputra, Director of Mataram City Hospital.

The key to his recovery, by keeping his mindset from stress, or always optimistic about his condition, keeping negative thoughts, guarded mood, filled with calmness, as long as in the isolation room he never accessed social media that contained panic about Covid-19. do light exercise in the hospital and still, pray to God for healing with patience through it. Furthermore Portal Islam.id edition 24 April 2020, the three patients were $\mathrm{AH}$ (47), W (43), H (15) from Panti Nugroho Regional Hospital were declared cured of Covid-19 key to recovery following all treatment procedures from hospital staff, read and listen to the Quran a lot. Furthermore Portal Islam.id edition 10 
April 2020, MQ, an Indonesian student in New York (USA), performs an independent quarantine at his place of residence without medical services. The peak was on the fifth day MQ could not get up from his tight bed and could not breathe chest-like breathing that he did through a message from Whatsapp (WA) sent a message of apology to parents and family, praying to pray two cycles while lying down, after praying reading the Surah Al- Fatihah and his two hands and sent the surah to himself by saying his name and his daughter. Furthermore, MQ prayed to God for healing from the coronavirus by doing Tapping therapy, which is tapping on several points on the face and hands continuously while praying with sincerity and surrender by asking God for healing. With great patience through it and on the 15th day, MQ was healthy.

From some Covid-19 patients who managed to recover it can be concluded that they made an effort or endeavor by isolating and following all the treatments given by health workers, doing light exercise, positive thinking and making spiritual journeys with prayer, remembrance, reading Quran and pray to Allah SWT solemnly and sincerely ask for healing and patiently live it.

\section{Patience Therapy Facing Covid-19}

Andi Mappiare (2006) says the word therapy and psychotherapy are commonly used in the medical field which means a corrective or curative process, or healing. Samsul Munir Amin (2010), said that psychotherapy comes from two syllables namely psycho and therapy. Psycho means soul, and therapy means healing. Thus, psychotherapy is healing the soul.

While Islamic psychotherapy, according to Adz-Dzakey (2008), is a process of treatment and healing through the guidance of the Koran and the Sunnah of the Prophet Muhammad s.a.w. or empirically is through the guidance and teaching of Allah, His Angels, His Apostles. Furthermore, Islamic psychotherapy can also be said to be treatment by using psychological tools for problems originating from emotional life, where an expert intentionally creates a professional relationship with clients/patients to eliminate, change, or reducing the symptoms that exist; repair damaged behavior; and promote positive personality growth and development. (Samsul Munir Amin, 2010).

Abd Al-Aziz Al-Khalidi in Abdul Mujib \& Jusuf Mudzakir (2002), dividing the two drugs to cure human diseases into two categories. First, Hissi medicine to cure physical diseases such as treatment with water, honey, and fruits mentioned in the Quran (olives, dates, figs). The second, Ma'nawi medicines for nonphysical medicine (soul and heart) such as prayers and the contents of the Koran. The division of these two categories of drugs is 
based on the assumption that in humans two substances combine into one, namely physical and spiritual. Each of these substances has its own Sunnah (law) which differs from one another.

Healing using Hissi drug therapy sourced from viruses has been proven by F. G. Sakeyt of the University of Colorado, in Abdul Basith Muhammad Sayyid (2008) by conducting experiments storing various kinds of germs and viruses in native honey. After waiting a few hours and days, the virus and germs die and disappear. Among the dead viruses are the viruses that cause typhoid fever that die after 48 hours, the viruses that cause typhoid fever and Parotyfud die after 24 hours, and the viruses that cause pneumonia to die on the fourth day.

Ibn Qoyyim in his book, Zaadul Ma'ad (2000), confirmed that honey can be used as a cure for all diseases including sourced from a virus, said, honey is a nutrient of all nutrients, medicine of all drugs, drinks of all drinks, the sweetness of all things sweet, ointment from all ointments (rubbing), refreshing from everything that is refreshing and the earlier people started it except with honey, and the Prophet drank it with water before breakfast.

Furthermore, healing by using drugs ma'nawi based on the Quran and the Sunnah of the Apostle in its application by using therapy. Eight models of therapy can be done to cure mental illnesses, including faith therapy, worship therapy, fasting therapy, pilgrimage therapy, istighfar and repentance therapy, remembrance therapy, prayer therapy, and finally patient therapy (al-Zahrani: 2005).

Ibn Qayyim al-Jauziyyah states patience in the spiritual sense means not despair and no panic, and holding the tongue from complaining (2010: 12). In the Koran surah Al-Baqarah: 153 it is mentioned that Allah asks believers to make patience and prayer as a solution in dealing with any problems including problems facing illness. His Word:

"O you who believe, make patience and prayer as your help, verily Allah is with those who are patient ".

This verse explicitly mentions that the condition of patience can be used as a form of an effort to solve a problem and invites you to decorate yourself with patience. Because, patience has a great advantage in fostering souls, strengthening personality, increasing human strength in enduring suffering, renewing human strength in facing various life problems, burdens of life, calamities, and disasters, as well as moving its ability to continue.

Musfir bin Said Az-Zahrani (2005) said that patience is a mental therapy because it has great benefits in educating the soul and strengthening the Muslim personality to increase his strength to be 
able to shoulder the burden of life. Next will renew the spirit to face all problems of life. A healthy soul transmits positive energy and at the same time strengthens the immune system within.

\section{Patient Therapy Techniques Overcoming anxiety Covid-19}

Sufism is one of the treasures of Islamic tradition and heritage with the conception of knowledge that emphasizes spirituality by interpreting the actions and words of the Prophet Muhammad SAW, who are laden with dimensions of spirituality and divinity as a method of achieving happiness and perfection in human life.

According to Mustafa Zahri (1995), the patient therapy method has three phases that must be passed to achieve selffilling into a healthy soul from the disease. First, the takhalli phase, namely cleaning oneself from the impurities of damaging liver disease (greed, 'ujub, riya', takabur, hasud, sum'ah) As for this stage techniques that can be used with self-control, the development of self-control through fasting, self-cleaning through zikrullah, fasting and reading the Qur'an, as well as self-denial.

Second, the tahalli phase, which is behaving by getting used to nature and attitude and good behavior. Trying that in every movement the behavior always goes above religious provisions. The techniques that can be used at this stage are the internalization of Asmaul Husna (appreciation of the names of Allah), imitating the Messenger of Allah, and the Friends, the development of hablun min alnas because humans are social creatures who cannot stand alone.

Third, the tajalli phase, meaning someone's heart is freed from the cover (hijab), which is getting nur (light) from Allah. This stage is also called the stage of increasing relations with God so that every worship performed by humans as creatures are not only ritualistic but also spiritual. Also at this stage, humans are taught how to bring up the Divine attributes within the limits of humanity.

Sufism patient therapy methods in a more detailed form can be done in the process of counseling and therapy. As for the initial stages (takhalli), the counselor asks the counselee to perform ablution and pray after $w u d u$ (ablution). The second stage is to perform the repentance prayer while performing the repentance prayer at the final prostration before greeting the counselee is asked to reveal all the sins that the counselee has committed as well as all who are a burden on his mind so far and ask for forgiveness from Allah by reading istighfar 41 times, after greetings The counselee is asked to read the following the statement by pervading the meaning "la ilaha illa anta subhanaka inni kuntu minal zhalimin". (There is no god but You, Your Most Holy, as surely as I am, 
including zalim). Finally, pray by reading Sayyidul Istighfar.

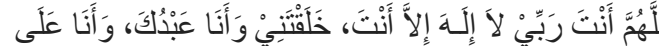

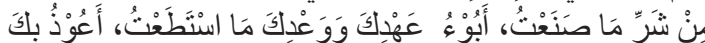

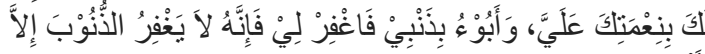

"O God, you are my Lord, there is no god but you who created me, while I am your servant and I am above your promise. And I promise you the best I can, I protect you from all the evil that I have done. I acknowledge You for your blessings against me and I confess my sins to You, then forgive me no one can forgive all sins except You"

At the stage of the tahalli technique where the counselor guides the story of Rasullah which has to do with the counselee's problem.

In the tajalli technique stage, by inviting the counselee to take a deep breath (relaxation) and close his eyes then read itighfar repeatedly while saying by saying "O God, I sincerely I resigned myself to pain (coronavirus/mention the problem) that happened to me and I beg for healing. the good from you ". Then come up with a strong belief that God will heal. (Luluk Dina, 2017)

Furthermore, Hamdani Bakran Adz Dzaky in his book Islamic counseling and psychotherapy (2008), explained therapy based on the verses of the Koran in dealing with mental illness in this case disorders of fear and anxiety have provided guidelines for healing methods.
The stages intend with the aim and intent that is straight and holy in a state of physical and spiritual holiness, the prayer of the two rakaahs, reading istighfar, reading the blessings of the prophet, reading Isti'adzah and basmalah, finally maintaining discipline, consistent and continuous, at least one month of khatam Quran (finishing reading the Quran wholly) or one week and read the Khatam Quran prayer as contained in every last sheet of the Qur'an's Manuscripts.

Ustaz Adi Hidayat on the TV show Quantum Akhyar (2020), said that in the face of the Covid-19 outbreak, a spiritual strengthening approach is needed to strengthen the immune system. When exposed to an illness or convicted of being part of a disease affected by corona, and other diseases it is recommended to read the Koran with full sincerity and strong request to Allah. If the Koran is read correctly there is a promise of God as promised by Allah to the Prophet Ayyub that any illness other than death, God will be pleased to cure it, while prayer requests healing from the plague Covid-19 performed after the prayer or at the last prostration, both prayer fardu, and sunnah prayer.

First, the do'a is found in Al-Qur'an Surah Al-Isra : 82. And Al-Anbiya: 83-84.

"And We send down from the Qur'an (something) that is an antidote and mercy for 
those who believe, while for those who do wrong (the Qur'an) will only add to the loss."

"And (remember the story) Job, when he prayed to his Lord," (O my Lord), truly, I have been afflicted with an illness, even though You are the Most Merciful God of all the merciful. So We grant (prayer), then We eliminate the disease that is there and we return the family to him, and (We double their number) as a mercy from Us, and to be a warning to all who worship Us."

Next, read the dua "allahumma anni massaniyadh-dhurru wa anta arhamur rahimin"(O God, my Lord, truly, I have been struck down by disease, even though You are the Most Merciful God of all the merciful). The last one, by closing with Surah Al-Fatihah: 1-7.

\section{CONCLUSION}

In the Quran, the test that comes to an unpleasant thing is always juxtaposed with patience. How to be patient in the Covid-19 pandemic condition does not mean resignation, silence but with the attitude of accepting all the decisions that God has given accompanied by endeavor and surrender all the results to God to accept that the ridge is patient. In Islamic psychotherapy, the patient is a model of treatment and healing therapy through the guidance of the Koran and the Sunnah of the Prophet Muhammad. Patient therapy can be used as an alternative way to deal with a Covid-19 pandemic situation, both those with anxiety neurosis and those who have contracted it. If Islamic psychotherapy is carried out perfectly, it will produce a potential for incentives, protective, and healing in humans so that this co-19 pandemic condition can be lived by having physical and mental health.

\section{REFERENCES}

Abdul, M., \& Mudzakir, J. (2002). NuansaNuansa Psikologi Islam. Jakarta: Persada Grafindo Persada.

Adz-Dzaky, Hamdani Bakran. (2008). Konseling dan Psikoterapi Islam. Jogjakarta: Al-Manar.

Al-Jauziyyah Ibnu Qayyim. (2010). Membeli Surga dengan Sabar dan Syukur, Yogyakarta: Golden Books.

Amin, S. M. (2010). Bimbingan dan Konseling Islam. Jakarta: Amzah.

Amin, S. M. (2000) Zuhud di Abad Modern. Yogyakarta: Pustaka Pelajar.

Annisa, D. F., \& Ifdil, I. (2016). Konsep Kecemasan (Anxiety). Konselor. https://doi.org/10.24036/020165264800-00

Az-Zahrani Musfir bin Said. (2005). Konseling Terapi. (terj. Sari Narulita \& Miftahul Jannah). Jakarta: Gema Insani.

Centers for Disease Control and Prevention. https://www.cdc.gov/coronavirus/201 9-ncov/prepare/managing-stressanxiety. 
De Groot, R. J., Baker, S. C., Baric, R., Enjuanes, L., Gorbalenya, A., Holmes, K. V., ... \& Woo, P. C. (2011). Virus taxonomy: classification and nomenclature of viruses.ninth report of the International Committee on Taxonomy of Viruses, 806-828

Departemen Agama RI (2006). Al-Qur'an dan Terjemahannya Jakarta: Lintas Media.

Detik.com. Update Corona di RI per 1 Mei. https://news.detik.com/berita/d4998753/update-corona-di-ri-per-1mei-10551-positif-1591-sembuh-800meninggal.

Dong, L., \& Bouey, J. (2020). Public mental health crisis during COVID-19 pandemic, China. Emerg Infect Dis, 26(7), 10-3201.

Halidi, R. (2020). Ahli Virus Sebut Covid19 Adalah Virus Umum. https://www.suara.com/health/2020/ 04/13/183832/ahli-virus-sebut-covid19-adalah-virus-umum-tetapi

Islamiyah, L. D. (2017). Terapi Sabar Dengan Teknik Sufistik (Takhalli, Tahalli, Tajalli) Untuk Mengatasi Stres Seorang Ibu Akibat Sudden Death Pada Anak Di Desa Mentaras Dukun Gresik (Doctoral dissertation, UIN Sunan Ampel Surabaya).

Kamus Kedoteran Dorland (2010). Penerbit: Buku Kedokteran.

Kartono, K \& Gulo, D. (1987). Kamus Psikologi Bandung: Pionir Jaya, PsychologyToday. https://www.psyc hologytoday.com/us/blog/why-badlooks-good/202003/how- coronavirus-anxiety-can-make-youfeel-sick.

Lahmuddin. (2012). Psikoterapi Dalam Perspektif Bimbingan Konseling Islami. MIQOT: Jurnal Ilmu-ilmu Keislaman, 36(2).

Legenhausen, M., \& Azim, S. (2010). Pengantar Penerjemah' Daras Filsafat Islam, terj. Musa Kazhim dan Soleh Baqir. Jakarta: Sadra Press.

Mappiare, A. (2006). Kamus Istilah Konseling dan Terapi. Jakarta: Raja Grafindo Persada.

Mohammad Arief Hidayat \& Satria Zulfikar. Pasien sembuh dari corona berbagi tips. https://www.vivanews.com/berita/ nasional/44504-pasien-sembuhdari-corona-berbagi-tips-jauhkandiri-dari-mediasosial?medium=autonext.

Muhammad Abi al-Qasim al-Husain bin al-Raghib al-Asfahani. (2009). AlMufradat al-Lafaz al-Qur'an, Damaskus: Dar al-Qalam.

Muhammad, S. A. B. (2008). Terapi Herbal dan Pengobatan Cara Nabi Saw. Penkerbar Plus. Jakarta.

Mustafa, Z. (1995). Kunci Memahami Ilmu Tasawuf. Surabaya: Bina Ilmu.

Primus, D. (2020). Perang Total Melawan Corona.

https://www.beritasatu.com/kesehata n/616141-perang-total-lawan-corona umat.

Purwakania, H. A. B. (2008). Psikologi Perkembangan Islam. Jakarta: Raja Grafindo Persada. 
Sugiyono. (2009). Metode Penelitian Kuantitatif, Kualitatif dan R\&D, Prosedur penelitian: Suatu Pendekatan Praktik. Edisi 14. Bandung.

Suryabrata, S. (2005). Psikologi Kepribadian. Jakarta: Raja Grafindo Persada.

Sutejo. (2018). Keperawatan Kesehatan Jiwa: Prinsip dan Praktek Asuhan Keperawatan Jiwa. Yogyakarta: Pustaka Baru Press.

Wahyouni. (2019). Doa Syaidul Istighfar. https://yufidia.com/4458-dzikirsayyidul-istighfar-istighfarterbaik.html.

Wheaton, M. G., Abramowitz, J. S., Berman, N. C., Fabricant, L. E., \&
Olatunji, B. O. (2012). Psychological predictors of anxiety in response to the H1N1 (swine flu) pandemic. Cognitive Therapy and Research, 36(3), 210-218.

World Health Organization (2019). Coronavirus Disease (COVID-19) Advice for The Public. https://www.who.int/emergencies/di seases/novel-coronavirus2019/events-as-they-happen

Yusfita, R. D. (2020). Pasien Dinyatakan Sembuh dari Covid-19 di Sumbar Masih $6 \quad$ orang. https://video.tribunnews.com/view/1 38141/pasien-sembuh-dari-viruscorona-berbagi-tips-untuk-berjuangjangan-cemas-dan-tetaplah-ceria. 